\title{
Human Impact on Spatial Water Temperature Variability in Lowland Rivers: a Case Study from Central Poland
}

\author{
Maksym Laszewski* \\ Department of Hydrology, Faculty of Geography and Regional Studies, University of Warsaw, \\ Krakowskie Przedmieście 30, 00-927 Warsaw, Poland
}

Received: 11 April 2017

Accepted: 21 June 2017

\begin{abstract}
Water temperature was monitored from May to October 2016 in the Świder and Utrata rivers, two lowland tributaries of the Vistula River in central Poland. Seven temperature recorders were located along each river continuum to examine both anthropogenic and natural factors affecting spatial temperature variability. The results showed that water temperature patterns in quasi-natural sites were generally similar across the length of the rivers. The most pronounced temperature increases were found to be the result of reservoir releases, wastewater inflows, and channel regulations. Riparian shade changes have also been identified as the main driver of spatial temperature heterogeneity, while the impact of the tributaries was not clear and depended on the degree of their anthropogenic transformation. Linear regression performance was similar in the case of most quasi-natural sites in the Świder River, while in the case of the Utrata River differences were found in explanatory power, slopes, and intercepts. Such investigations of water temperature patterns indicate that in lowland rivers temperature variations can be spatially complex and significant in their magnitudes, thus current research could help in the context of riverine management - especially for fisheries and environmental protection.
\end{abstract}

Keywords: water temperature, lowland rivers, anthropopressure, catchments

\section{Introduction}

Temperature can be considered as one of the most fundamental water quality parameter critical in terms of such river biota as invertebrates and fish [1]. For example, there is widespread acceptance of the effect temperature has on the growth and survival of fish [2] and their migration [3], as well as the duration

*e-mail: m.laszewski@uw.edu.pl of spawning, egg development, and hatching [4]. In consequence, temperature was widely recognized as a crucial parameter in stream ecology [5]. Together with all environmental implications, the thermal variability of streams and rivers has generated considerable attention in recent years [6]. Studies have focused primarily on temperature heterogeneity from catchment to channel scales [7], on the relationships between landscape metrics and thermal regime parameters [8], and on forest cover impacts on temperature characteristics [9]. Most of the papers concentrated on streams in marine and oceanic types of climate (usually of mountains and foothills) 
where populations of salmon or other salmonid fish are present [10-11]. In turn, the water temperature of rivers flowing throughout lowland plains in Central and Eastern Europe has received relatively limited attention in scientific literature. However, due to the high degree of human alternations in catchment areas, the thermal regime of such rivers is often highly transformed, and their longitudinal temperature patterns could be complex.

Today, remote sensing techniques provide great possibilities for capturing the spatial heterogeneity of river water temperatures [12]. For example, airborne thermal imagery has revealed the need to reconsider the dominant paradigm of longitudinal stream water temperature profiles because the mean temperature does not always rise asymptotically with river length [13]. Despite the significant benefits of remote sensing, it must be emphasized that such techniques are expensive and hard to apply in the case of small rivers covered by riparian shade [14]. On the other hand, temperature data from government networks are often spatially and temporally poor. For example, water temperature in Poland is measured only once a day at 06:00 UTC in selected gauging stations [15]. Thus, faced with the perspective of the lack of reliable, spatially extensive temperature data for most of the lowland rivers, measurement campaigns using temperature recorders are definitely still the simplest and the most cost-effective method of thermal variability research.

The objective of the current study is to explain longitudinal water temperature changes in two small lowland rivers subjected to several anthropogenic modifications. The specific aims of the study were to:

1. Characterize spatial variations of water temperature metrics in the reach scale of the rivers.

2. Investigate dominant anthropogenic and natural disturbances to the thermal regime.

3. Examine the performance of air-water linear models in the context of thermal regime alternations.

\section{Materials and Methods}

\section{The Study Area}

The study was conducted in two lowland catchments located in central Poland in the proximity of the Warsaw urban agglomeration - both belonging to the Vistula River catchment (Fig. 1). The Świder River has a length of $99 \mathrm{~km}$ while the Utrata River is $78.2 \mathrm{~km}$, with total catchment areas of 1,158 and $804 \mathrm{~km}^{2}$, respectively. Catchments span an altitudinal range of $137 \mathrm{~m}$ at the most upstream site investigated on the Swider to $83 \mathrm{~m}$ in the most downstream profile of the Utrata. The climate of the catchments is considered temperate in the transition zone from marine to continental with long-term annual precipitation in the sum of $550 \mathrm{~mm}$ and a mean annual air temperature of $8-9^{\circ} \mathrm{C}$. The solid geology of the catchments is dominated by sandstone, mudstone, and claystone, while the streambed of the rivers is mainly built of medium and coarse sand with the local addition of boulders. In quasi-natural reaches banks are covered with riparian vegetation dominated by medium-height trees and shrubs, such as willows, aspens, and black alders. According to the Corine Land Cover 2012 database, land use varies in the catchments. In the Utrata catchment agricultural areas constitute $68 \%$ of the total catchment area, urbanized areas $22.1 \%$, and forested areas only $9 \%$. In the case of the Świder, the agricultural areas amount to a similar percentage (62.3\%), while the urbanized and forested areas amount to $8.3 \%$ and $29 \%$, respectively. Together with land use, the investigated rivers are characterized by different degrees of anthropogenic modification. The Świder, which is partially under reserve protection, has maintained a quasi-natural character from site S4 to the mouth, with pool-riffle channel sequences and dense riparian vegetation. However, the river was regulated from sites $\mathrm{S} 1$ to $\mathrm{S} 3$ in the middle of the $20^{\text {th }}$ century when small weirs were built approximately

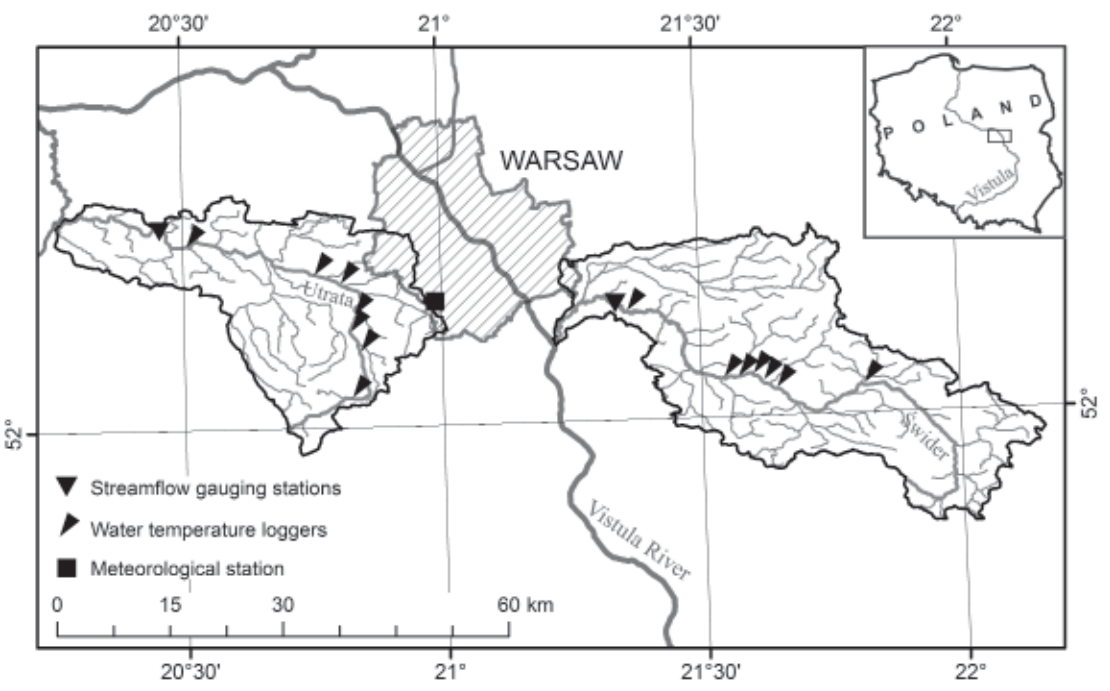

Fig. 1. Study area with the locations of temperature recorders. 
every $1 \mathrm{~km}$ apart, which resulted in reduced flow velocity and depth locally of up to $2 \mathrm{~m}$. In contrast, the Utrata is commonly considered heavily transformed, without sections from its springs to site U3. Upstream from site U4 a small shallow reservoir was built. From sites U5 to U7 the river channel was completely regulated, while riparian trees and shrubs were removed. Today, more than 40 municipal and industrial wastewater treatment plants (WWTP) are functioning in the river catchment [16]. The largest is located in Pruszków, and its maximum daily sewage capacity is up to $69,000 \mathrm{~m}^{3}$.

\section{Measurement Data}

The water temperature data was provided from measurements conducted with the use of Hobo U22-001 and UA-001-08 digital data loggers (Onset Computer Corporation). The accuracy of the devices, according to manufacturer information, was $0.2^{\circ} \mathrm{C}$ and $0.4^{\circ} \mathrm{C}$, respectively. Loggers were additionally checked by the "ice bucket" method - differences between measurements in $0.0^{\circ} \mathrm{C}$ were up to $0.07^{\circ} \mathrm{C}$ and $0.12^{\circ} \mathrm{C}$ in the case of U22-001 and UA-001-08, respectively. During the study period each logger was additionally controlled once a month with a NIST handheld thermometer. This allowed to confirm whether water temperature recorded by the logger at a given point was uniform with temperature measured in the cross-section of the channel. The water temperature network was designed to identify temperature changes with the use of loggers that contribute to long-term monitoring and provide data from upper, middle, and downstream reaches of both the Świder and the Utrata [17]. Four additional loggers were installed in middle sections of the rivers to examine the influence of substantial changes in riparian use, channel regulation, and reservoir releases, as well as inflows from WWTP and tributaries (Table 1). Apart from investigative purposes, sites were chosen in straight and relatively turbulent types of flow sections. To provide maximum reliability of the results, temperature recorders were installed inside perforated PVC pipes, which were attached to large pieces of wood or were bolted to small blocks of concrete. Water temperature was recorded from the 1 May to 31 October 2016. The temporal resolution of the measurements was 30 minutes.

Hydrometeorological context was provided by mean daily air temperature and precipitation data from Warsaw Okęcie meteorological station, as well as by streamflow data from gauging stations operated by the Institute of Meteorology and Water Management - National Research Institute, located near the most downstream measurement site in Krubice (the Utrata) and Wólka Mlądzka (the Świder). Site properties such as the distance from the source and catchment area were estimated on the basis of digital hydrographic maps in the GIS software. Riparian shade was simply quantified with the use of aerial photographs available on a public geoportal of Poland. The percentage of banks covered with dense riparian trees was approximated for these purposes in sections $2 \mathrm{~km}$ upstream from each site. Width:depth ratios were calculated on the basis of measurements in site crosssections during a low flow period in August.

Table 1. Characteristics of measurement sites.

\begin{tabular}{|c|c|c|c|c|c|}
\hline Site & $\begin{array}{c}\text { Distance from } \\
\text { the source } \\
{[\mathrm{km}]}\end{array}$ & $\begin{array}{c}\text { Catchment } \\
\text { area } \\
{\left[\mathrm{km}^{2}\right]}\end{array}$ & $\begin{array}{c}\text { Width:depth } \\
\text { ratio } \\
{[-]}\end{array}$ & $\begin{array}{c}\text { Riparian } \\
\text { shade } \\
{[\%]}\end{array}$ & Site description \\
\hline S1 & 32.3 & 219.5 & 12.0 & 20 & Quasi-natural reach \\
\hline S2 & 46.7 & 496.9 & 8.8 & 5 & Regulated reach \\
\hline S3 & 48.8 & 542.4 & 9.4 & 10 & Regulated reach, downstream from tributary inflow \\
\hline S4 & 51.0 & 550.0 & 13.3 & 30 & Quasi-natural reach \\
\hline S5 & 52.4 & 640.3 & 11.9 & 50 & Natural reach, downstream from large tributary inflow \\
\hline S6 & 54.5 & 644.5 & 11.3 & 90 & Natural forested reach \\
\hline S7 & 79.3 & 853.3 & 13.8 & 85 & Natural forested reach \\
\hline U1 & 10.3 & 35.6 & 14.0 & 60 & Quasi-natural reach \\
\hline U2 & 19.3 & 57.2 & 8.5 & 35 & Backwater of the small weir, regulated channel \\
\hline U3 & 24.7 & 91.5 & 10.7 & 80 & Natural, forested reach \\
\hline U4 & 26.2 & 103.6 & 12.0 & 70 & Quasi-natural channel, 200 meters below reservoir \\
\hline U5 & 32.3 & 198.4 & 10.6 & 55 & Regulated reach downstream from tributary inflow and \\
\hline U6 & 35.8 & 241.2 & 9.9 & 10 & Regulated reach downstream from Pruszków WWTP \\
\hline U7 & 55.0 & 661.0 & 10.4 & 0 & Regulated reach \\
\hline
\end{tabular}




\section{Statistical Analysis}

On the basis of measurement data, temperature metrics were calculated for the whole study period and for monthly time scales. Mean, maximum, and minimum water temperatures were selected as magnitude parameters, and the mean daily range as the rate of temperature fluctuations. To establish the existence of statistically significant differences between the nearest sites, the Wilcoxon signed rank test (WSR) was used on pair loggers moving downstream. The WSR test was selected as a non-parametric test due to working with a non-normally distributed water temperature data set, and it was run for all temperature metrics (daily mean, maximum, minimum, and range). The large number of observations resulted in the selection of a more restrictive alpha $(\alpha=0.01)$. Finally, linear air-water temperature relationships were developed to assess how explanatory power $\left(\mathrm{R}^{2}\right)$ and model parameters (a: intercept, b: slope) are related to the varied types of thermal regime transformation. Regression models were produced using daily mean air temperature from the nearest meteorological station Warsaw Okęcie and daily mean water temperature from all investigated sites. Data analysis was conducted using Statistica 12.0 software.

\section{Results}

\section{Hydrometeorological Background}

Air temperature and precipitation in the study period are presented in Fig. 2a). Overall, summer 2016 was characterized by a typical seasonal air temperature pattern. Maximum daily mean temperature occurred in June, reaching as high as $27.7^{\circ} \mathrm{C}$, and the minimum occurred in October, measuring only $4.3^{\circ} \mathrm{C}$. Mean air temperature in the study period was $16.4^{\circ} \mathrm{C}$, while the sum of precipitation reached $340 \mathrm{~mm}$. However, the latter was not distributed regularly throughout the season: relatively low sums of monthly precipitation were noted in August and September $(59$ and $11 \mathrm{~mm}$, respectively), while October, with a monthly sum of $110 \mathrm{~mm}$, was extremely wet. As a result, low streamflow was observed during the warmest period (Fig. 2b), which made the water temperature more sensitive to both anthropogenic and natural alternations and favored the appearance of clear longitudinal contrasts. Such a situation persisted until the end of September, when the wet and cold period began and streamflow rates became definitely higher.

\section{Spatial Patterns of Water Temperature}

The water temperature of the Świder and the Utrata rivers varied between the sites (Fig. 3) and spatial temperature patterns were found in the case of all four temperature metrics (Figs 4-5). However, clear differences in the magnitude of thermal contrasts existed between the

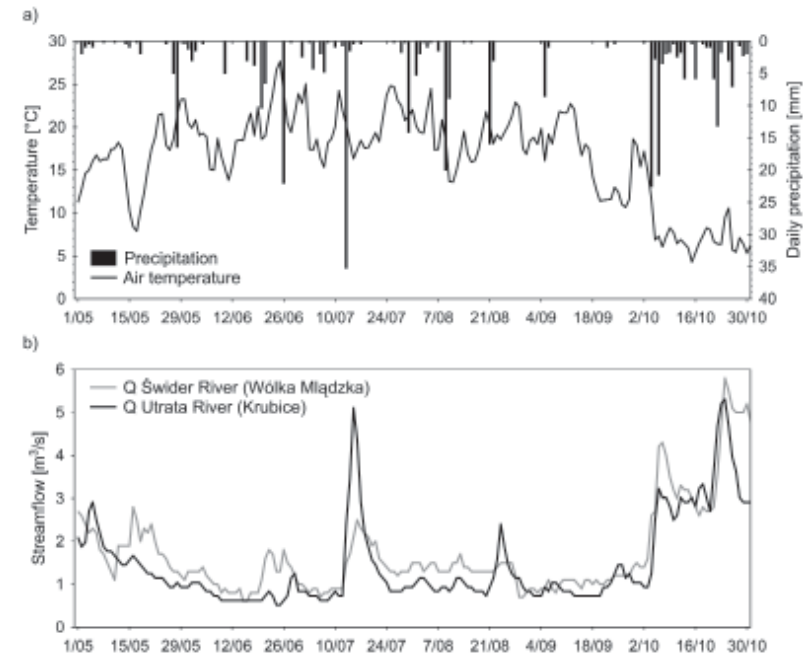

Fig. 2. Mean daily air temperature and precipitation from a) the Warsaw Okęcie meteorological station and b) mean daily streamflow in the Krubice and Wólka Mlądzka gauging stations.

two investigated rivers, as the Utrata showed a definitely higher complexity of thermal behavior and indicated a strong contribution of anthropogenic impacts.

More detailed analysis of longitudinal water temperature changes showed that the mean summer temperature in the Świder was generally the lowest in the most upstream site $\mathrm{S} 1\left(16.1^{\circ} \mathrm{C}\right)$, while sites $\mathrm{S} 2$ and $\mathrm{S} 3$ were the warmest (both with temperatures of $16.5^{\circ} \mathrm{C}$ ), representing the end of the reach with a regulated, deep channel without riparian trees. Downstream from S3 a general colling effect was observed in terms of mean temperatures. A slightly different longitudinal pattern was found in the Utrata, where the mean summer temperature was the lowest at site $\mathrm{U} 3\left(15.5^{\circ} \mathrm{C}\right)$, but only a slightly higher mean temperature was noted in the most upstream sites $\mathrm{U} 1\left(15.7^{\circ} \mathrm{C}\right)$ and $\mathrm{U} 5\left(15.8^{\circ} \mathrm{C}\right)$. The

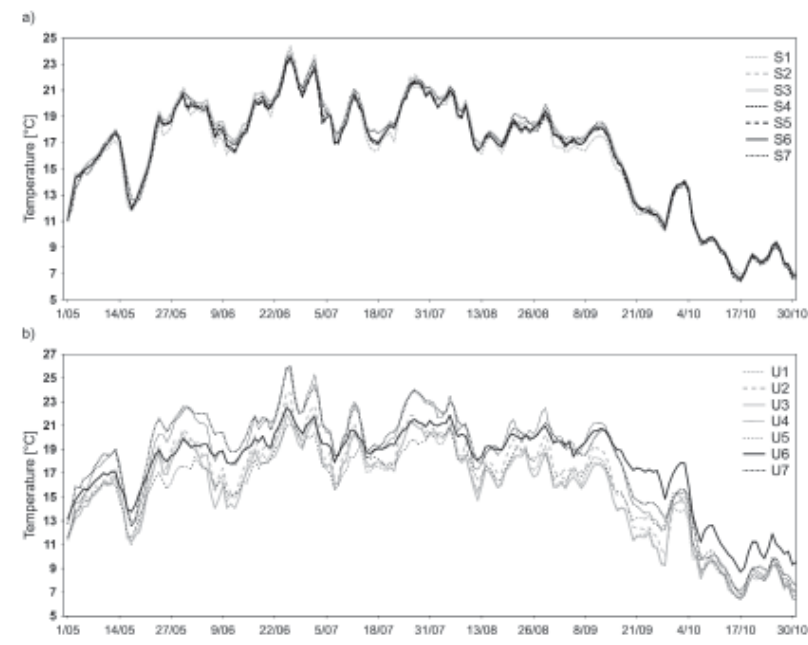

Fig. 3. Water temperature patterns from all investigated sites on a) the Świder River, and b) the Utrata River, based on daily mean values. 
highest mean summer temperature was observed in the most downstream regulated site, $\mathrm{U} 7\left(18.0^{\circ} \mathrm{C}\right)$, although similar temperatures were also found in sites U4 and U6 (both $17.7^{\circ} \mathrm{C}$ ), located downstream from the reservoir release and sewage inflow, respectively. From a site-tosite perspective, significant differences in daily mean temperatures were found in nearly all of the paired sites, with the exception of pair S4/S5 on the Świder ( $p>0.01$ ).
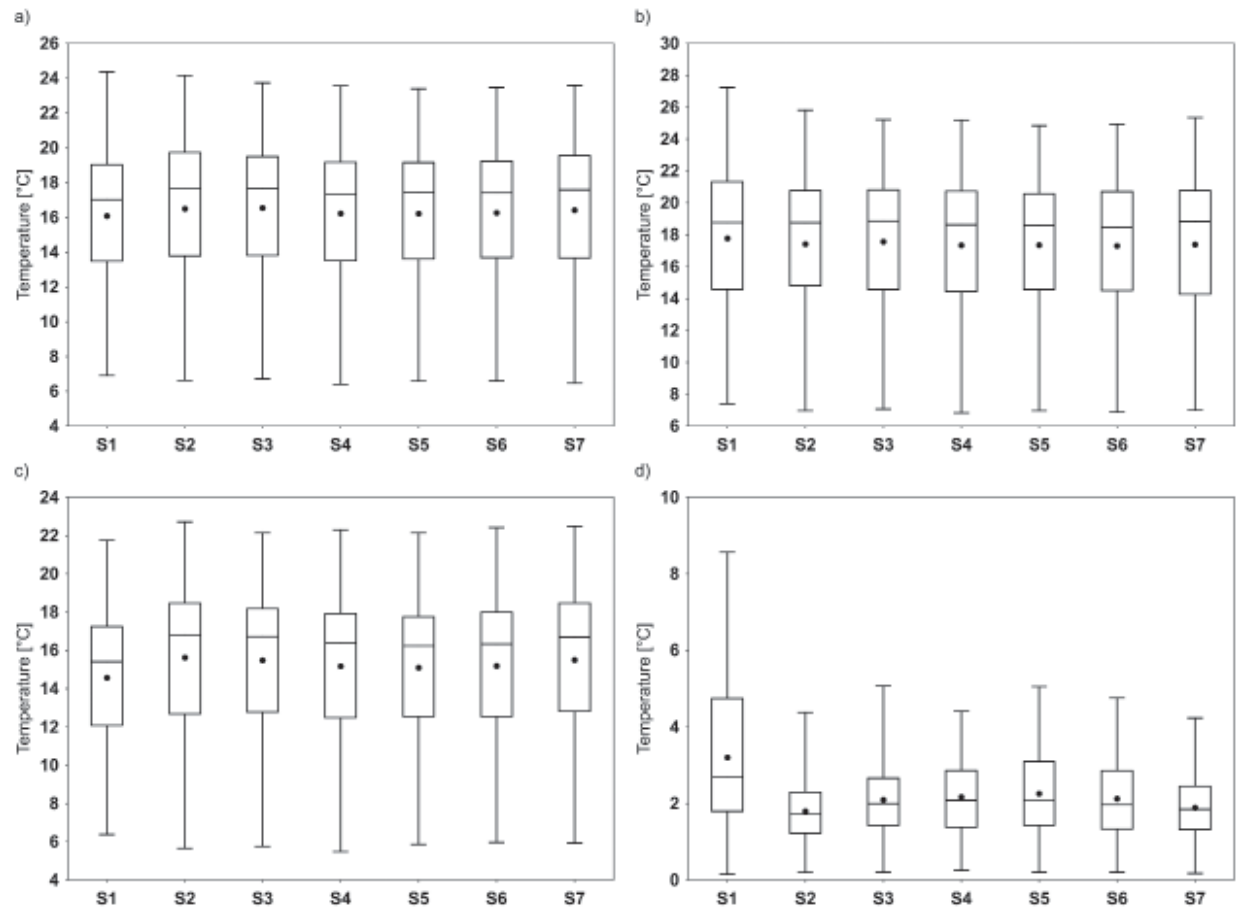

Fig. 4. Distribution of daily mean a), maximum b), minimum c), and range d) water temperature data across all sites on the Świder River. The plot shows mean (dots), the $25^{\text {th }}$ and $75^{\text {th }}$ percentile (boxes around the median line), and minimum and maximum temperature (whiskers).
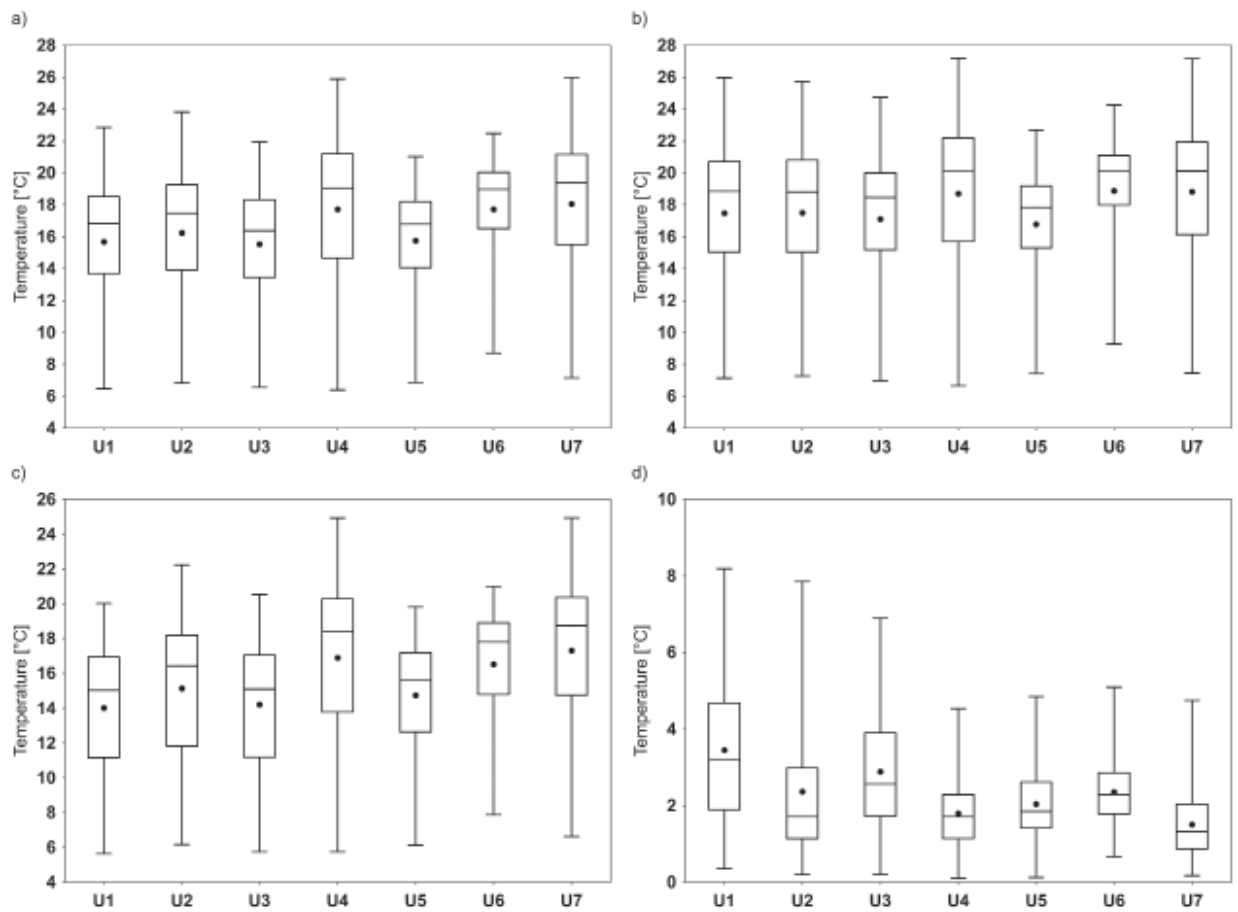

Fig. 5. Distribution of daily mean a), maximum b), minimum c) and range d) water temperature data across all sites in the Utrata River. The plot shows mean (dots), the $25^{\text {th }}$ and $75^{\text {th }}$ percentile (boxes around the median line), and minimum and maximum temperature (whiskers). 
Table 2. Descriptive water temperature parameters calculated from $30 \mathrm{~min}$ of data for all investigated sites.

\begin{tabular}{|c|c|c|c|c|c|c|c|c|c|c|c|c|c|c|c|}
\hline & & S1 & S2 & S3 & S4 & S5 & S6 & S7 & U1 & U2 & U3 & U4 & U5 & U6 & U7 \\
\hline \multirow{4}{*}{ May 2016} & Mean & 15.8 & 16.3 & 16.4 & 16.1 & 16.1 & 16.1 & 16.1 & 15.6 & 16.0 & 15.4 & 17.3 & 15.0 & 16.6 & 17.9 \\
\hline & Maximum & 24.9 & 22.2 & 23.1 & 22.9 & 22.8 & 22.4 & 22.6 & 23.6 & 24.0 & 23.5 & 23.5 & 18.7 & 21.8 & 23.9 \\
\hline & Minimum & 9.8 & 10.2 & 10.1 & 10.2 & 10.3 & 10.3 & 10.7 & 8.6 & 9.3 & 9.2 & 11.2 & 10.4 & 11.4 & 11.7 \\
\hline & Mean daily range & 5.0 & 2.6 & 3.1 & 3.3 & 3.4 & 3.2 & 2.2 & 6.0 & 5.4 & 5.0 & 2.4 & 3.0 & 3.4 & 2.5 \\
\hline \multirow{4}{*}{ June 2016} & Mean & 19.5 & 20.1 & 20.1 & 19.8 & 19.5 & 19.5 & 19.7 & 18.4 & 19.0 & 17.7 & 21.0 & 17.8 & 19.7 & 21.6 \\
\hline & Maximum & 27.2 & 25.8 & 25.2 & 25.2 & 24.8 & 24.9 & 25.3 & 26.0 & 25.7 & 24.7 & 27.1 & 22.7 & 24.3 & 27.2 \\
\hline & Minimum & 13.0 & 15.1 & 16.2 & 14.8 & 13.9 & 13.8 & 14.5 & 11.3 & 13.8 & 11.3 & 16.7 & 13.7 & 16.7 & 17.7 \\
\hline & Mean daily range & 5.3 & 2.1 & 2.2 & 2.7 & 3.2 & 3.1 & 2.6 & 5.0 & 2.4 & 3.9 & 2.1 & 2.5 & 2.5 & 2.0 \\
\hline \multirow{4}{*}{ July 2016} & Mean & 19.4 & 19.7 & 19.6 & 19.4 & 19.3 & 19.4 & 19.9 & 18.9 & 19.4 & 18.9 & 21.3 & 18.4 & 20.0 & 21.3 \\
\hline & Maximum & 26.2 & 25.3 & 24.4 & 24.8 & 24.4 & 24.2 & 25.4 & 24.5 & 24.0 & 23.9 & 27.2 & 22.0 & 23.4 & 25.5 \\
\hline & Minimum & 15.1 & 16.1 & 15.8 & 15.5 & 15.4 & 15.6 & 16.1 & 14.0 & 15.5 & 14.0 & 17.3 & 14.4 & 17.1 & 17.2 \\
\hline & Mean daily range & 3.6 & 2.0 & 2.4 & 2.3 & 2.2 & 2.0 & 2.0 & 3.0 & 2.0 & 2.6 & 1.9 & 2.1 & 2.1 & 1.6 \\
\hline \multirow{4}{*}{ August 2016} & Mean & 18.2 & 18.7 & 18.8 & 18.4 & 18.4 & 18.5 & 18.8 & 17.9 & 18.6 & 17.8 & 20.4 & 18.3 & 20.0 & 20.4 \\
\hline & Maximum & 23.0 & 22.3 & 22.9 & 22.4 & 22.5 & 22.3 & 22.4 & 22.8 & 22.5 & 22.9 & 25.5 & 22.3 & 23.4 & 24.2 \\
\hline & Minimum & 14.6 & 16.0 & 15.9 & 15.4 & 15.1 & 15.0 & 15.1 & 13.7 & 14.0 & 13.3 & 16.4 & 15.2 & 16.8 & 17.1 \\
\hline & Mean daily range & 2.7 & 1.6 & 2.2 & 1.9 & 2.0 & 2.0 & 1.9 & 2.7 & 1.8 & 2.3 & 2.0 & 1.8 & 2.1 & 1.3 \\
\hline \multirow{4}{*}{ September 2016} & Mean & 14.5 & 15.1 & 15.2 & 14.9 & 14.9 & 15.0 & 15.1 & 14.5 & 15.2 & 14.2 & 17.2 & 15.4 & 18.5 & 17.3 \\
\hline & Maximum & 18.5 & 19.5 & 19.1 & 19.3 & 19.1 & 19.2 & 19.8 & 20.0 & 19.9 & 19.2 & 22.0 & 18.8 & 22.0 & 21.0 \\
\hline & Minimum & 9.4 & 10.5 & 9.8 & 9.4 & 9.8 & 9.9 & 9.4 & 7.6 & 9.1 & 7.8 & 10.5 & 11.7 & 13.5 & 12.9 \\
\hline & Mean daily range & 2.0 & 1.5 & 1.8 & 1.9 & 1.9 & 1.8 & 1.9 & 3.0 & 1.6 & 2.4 & 1.6 & 1.8 & 2.3 & 0.9 \\
\hline \multirow{4}{*}{ October 2016} & Mean & 9.2 & 9.1 & 9.2 & 8.9 & 9.1 & 9.1 & 9.0 & 8.9 & 9.3 & 9.1 & 9.1 & 9.6 & 11.6 & 9.9 \\
\hline & Maximum & 14.7 & 14.9 & 14.6 & 14.6 & 14.6 & 14.5 & 14.4 & 15.2 & 15.1 & 15.7 & 15.9 & 15.7 & 19.0 & 16.0 \\
\hline & Minimum & 6.4 & 5.7 & 5.8 & 5.5 & 5.9 & 6.0 & 5.9 & 5.6 & 6.2 & 5.8 & 5.8 & 6.1 & 7.9 & 6.6 \\
\hline & Mean daily range & 0.8 & 1.0 & 0.9 & 0.9 & 0.8 & 0.8 & 0.7 & 1.1 & 1.0 & 1.1 & 0.8 & 1.0 & 1.8 & 0.7 \\
\hline \multirow{4}{*}{ Summer 2016} & Mean & 16.1 & 16.5 & 16.5 & 16.2 & 16.2 & 16.3 & 16.4 & 15.7 & 16.2 & 15.5 & 17.7 & 15.8 & 17.7 & 18.0 \\
\hline & Maximum & 27.2 & 25.8 & 25.2 & 25.2 & 24.8 & 24.9 & 25.4 & 26.0 & 25.7 & 24.7 & 27.2 & 22.7 & 24.3 & 27.1 \\
\hline & Minimum & 6.0 & 5.7 & 5.8 & 5.5 & 5.9 & 6.0 & 5.9 & 5.6 & 6.2 & 5.8 & 5.8 & 6.1 & 7.9 & 6.6 \\
\hline & Mean daily range & 3.2 & 1.8 & 2.1 & 2.2 & 2.3 & 2.1 & 1.9 & 3.4 & 2.4 & 2.9 & 1.8 & 2.0 & 2.4 & 1.5 \\
\hline
\end{tabular}

Absolute summer maximum water temperature in the Swider was the highest in the most upstream site, $\mathrm{S} 1\left(27.2^{\circ} \mathrm{C}\right)$, and decreased to reach a minimum value of $24.8^{\circ} \mathrm{C}$ in site $\mathrm{S} 5$; downstream to site $\mathrm{S} 7$ a small increase in maximum temperature was observed, but only of $0.6^{\circ} \mathrm{C}$. A similar pattern was observed in terms of average maximum temperature for the whole period (Fig. 4). In the case of the Utrata, the lowest maximum summer water temperature was recorded in site U5, where this metric only reached $22.7^{\circ} \mathrm{C}$, while the highest was noted at $\mathrm{U} 4$, reaching $27.2^{\circ} \mathrm{C}$. On average, maximum water temperature was the highest at U6, downstream from the WWTP inflow (Fig. 5). Significant differences between daily maximum temperatures were found in nearly all of the paired sites, with the exception of pairs S4/S5 and S6/ $\mathrm{S} 7$ in the case of the Swider and U1/U2 in the case of the Utrata $(\mathrm{p}>0.01)$.

Absolute minimum water temperature was generally uniform in all of the investigated sites, with a difference of $0.5^{\circ} \mathrm{C}$ in the case of the Swider. On average, the highest minimum temperatures were noted in site S2, while the lowest were at S1. A similar pattern was found in the case of the Utrata, where absolute minimum water temperature varied only by $1^{\circ} \mathrm{C}$; with the single exception of site U6, downstream from WWTP $\left(7.9^{\circ} \mathrm{C}\right)$. However, on average, site U1 was the coldest, while sites U4 and U7 were the warmest. Statistical tests showed that in all paired sites in both the Świder and the Utrata, daily 
Table 3. Summary of linear models between daily mean air and water temperatures for all investigated sites.

\begin{tabular}{|c|c|c|c|}
\hline Site & R2 & Slope (a) & Intercept (b) \\
\hline S1 & 0.84 & 0.72 & 4.06 \\
\hline S2 & 0.85 & 0.75 & 4.02 \\
\hline S3 & 0.84 & 0.74 & 4.26 \\
\hline S4 & 0.85 & 0.73 & 4.00 \\
\hline S5 & 0.85 & 0.72 & 4.27 \\
\hline S6 & 0.85 & 0.72 & 4.27 \\
\hline S7 & 0.84 & 0.74 & 4.01 \\
\hline U1 & 0.89 & 0.71 & 3.79 \\
\hline U2 & 0.90 & 0.74 & 3.94 \\
\hline U3 & 0.87 & 0.70 & 4.04 \\
\hline U4 & 0.89 & 0.86 & 3.35 \\
\hline U5 & 0.85 & 0.61 & 5.50 \\
\hline U6 & 0.84 & 0.58 & 8.02 \\
\hline U7 & 0.86 & 0.80 & 4.77 \\
\hline
\end{tabular}

minimum water temperature was significantly different; the only exception was pair $\mathrm{S} 4 / \mathrm{S} 5$ ( $\mathrm{p}>0.01)$.

Generally, in both investigated rivers mean daily temperature fluctuations were the highest in the most upstream sites and decreased downstream. In the Świder the highest mean daily range was noted in site $\mathrm{S} 1\left(3.2^{\circ} \mathrm{C}\right)$, while the lowest was in site $\mathrm{S} 2\left(1.8^{\circ} \mathrm{C}\right)$. For sites $\mathrm{S} 4$ to $\mathrm{S} 6$ temperature variations were slightly higher, but in the most downstream site, S7 temperature dynamics decreased $\left(1.9^{\circ} \mathrm{C}\right)$. In the Utrata mean daily temperature fluctuations also generally decreased downstream, from $3.4^{\circ} \mathrm{C}$ at $\mathrm{U} 1$ to $1.5^{\circ} \mathrm{C}$ at $\mathrm{U} 7$, although small daily temperature variations were also found below the reservoir release at $\mathrm{U} 4$ $\left(1.8^{\circ} \mathrm{C}\right)$. All paired sites were characterized by significant differences in this metric on the Utrata; the situation was slightly different in the case of the Świder, where between $\mathrm{S} 3$ and $\mathrm{S} 4$, and $\mathrm{S} 4$ and $\mathrm{S} 5$, there was no significant change between mean daily temperature range $(\mathrm{p}>0.01)$.

Spatial patterns of water temperature varied temporally, as indicated by different temperature metrics in the monthly time scale (Table 2). Generally, in the case of both rivers the most pronounced temperature contrasts occurred during the warmest, low-flow period, mainly from June to August. Temperature was definitely less varied in the case of the Świder, where differences in mean temperature only amounted to $0.7^{\circ} \mathrm{C}$ in September. The maximum temperature parameter in this river was the most varied in May $\left(2.7^{\circ} \mathrm{C}\right)$, while minimum and mean daily temperatures were the most varied in June $\left(3.3^{\circ} \mathrm{C}\right.$ and $3.2^{\circ} \mathrm{C}$, respectively). Differences in water temperature across sites in the Utrata were clearly higher in monthly scales. Mean temperature was most varied in September, even by $4.3^{\circ} \mathrm{C}$. The same is true of minimum water temperature $\left(5.9^{\circ} \mathrm{C}\right)$. This was mainly due to elevated water temperatures observed at U6. Maximum and mean daily range metrics differed the most throughout May, reaching $5.3^{\circ} \mathrm{C}$ and $3.6^{\circ} \mathrm{C}$, respectively. Temperature patterns were uniform in nearly all investigated sites in October.

\section{Linear Regression Models}

Linear regression models produced for daily mean air and water temperatures explained at least $84 \%$ of water temperature variations in the case of both investigated rivers (all regression models were statistically significant at $\mathrm{p}<0.01$ ) (Table 3). The explanatory power for all sites on the Świder was similar (0.84-0.85), while slightly higher differences were found in the case of the Utrata (0.84$0.90)$. Generally, the explanatory power of the regression models was the highest and most similar in the upstream reach of the Utrata and decreased downstream in sites U5 and U6, while in the case of the Świder the explanatory power was quite uniform from upstream to downstream. The slopes of the regression models varied from 0.72 to 0.75 and 0.58 to 0.86 in the case of the Świder and Utrata, respectively. Together with slope, intercept also showed a similar tendency; in the Świder intercept varied from 4.00 to only 4.27 , while in the Utrata from 3.35 to even up to 8.02 (Fig. 6).

\section{Discussion and Conclusions}

Detailed stream temperature monitoring in two lowland catchments provided a contribution to better understand thermal variability and demonstrated the fundamental effect of human impact as a key factor influencing spatial temperature changes. Such anthropogenic alternations of thermal regimes, sometimes overlapping each other, are common in the case of many lowland rivers flowing throughout urbanized and agricultural areas. This in turn has proven to be crucial from the point of view of aquatic ecology, as population structure, growth conditions, and the feeding strategies of certain fish species could vary among the stream reaches [11, 18]. Thus, such investigations, which help environmental managers take into account a magnitude of varied human impacts, could have a practical significance in the context of fisheries, ecosystem protection, and other conservation issues [19].

\section{Factors Affecting Thermal Variability}

Many different factors affecting longitudinal temperature changes, both anthropogenic and natural, have been investigated in previous research [6]. The most common human impacts on the river thermal continuum are definitely dam and weir operations [20], inflows from wastewater treatment [21] and power plants [22], and land use changes [23]. The thermal continuum may also be disrupted by natural factors, such as tributary inflows and groundwater inputs [24], as well as different degrees 
a)

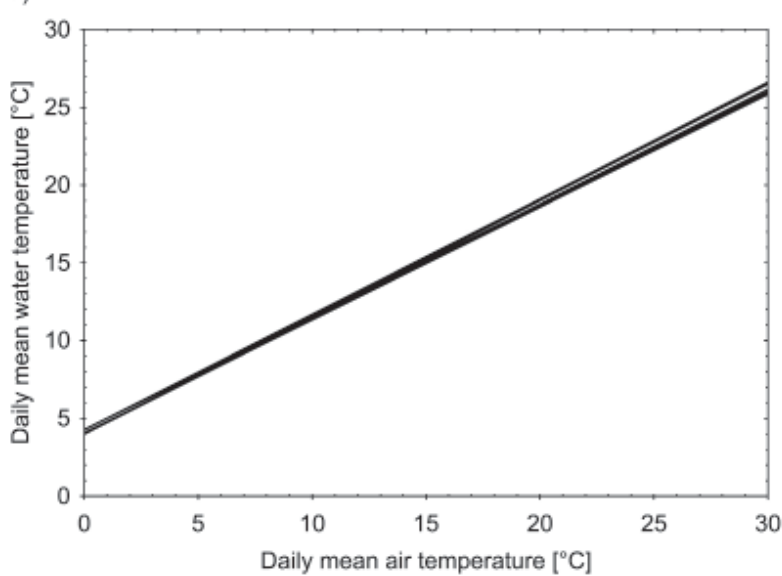

b)

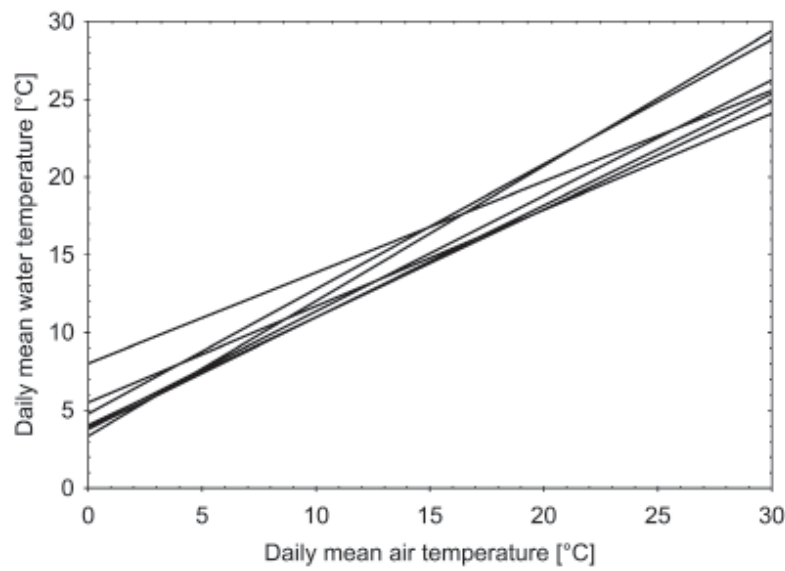

Fig. 6. Linear relationships between mean daily water and air temperatures for all investigated sites in a) the Świder River, and b) the Utrata River.

of shading [25]. As detailed below, a complex set of human alternations was identified to create a longitudinal heterogeneity of water temperature in the current study.

First of all, the most rapid increase of mean, maximum, and minimum water temperature parameters and a reduction of daily temperature fluctuations was observed below the shallow reservoir without thermal stratification (site U4), where water is released from a warm surface layer. Such an effect is consistent with the findings of [26], who found an average increase of mean summer temperature of $2.7^{\circ} \mathrm{C}$ below selected small surface release dams in the United States; congenial influence were observed by [19] in the case of headwater streams in the U.S. state of South Carolina. It must be emphasized that a few kilometers downstream from U4 there was also a colling effect of the deeper reservoir in site U5, but its magnitude is difficult to evaluate due to the simultaneous impact of a considerable tributary (detailed below).

Sewage inflows from a wastewater treatment plant were also found to greatly affect the river thermal regime (site U6); however, this impact was especially clear during September and October, when a significant increase of water temperature by even $5^{\circ} \mathrm{C}$ was noted. During the warm periods the heating effect of WWTP could be considered to be relatively small; for example, in the hottest day of 2016 sewage inflows from WWTP increased the daily mean temperature by $1.5^{\circ} \mathrm{C}$, in comparison to $4.0^{\circ} \mathrm{C}$ and $3.8^{\circ} \mathrm{C}$ increases due to shallow reservoir releases and channel regulation, respectively. This confirmed the conclusions of [27] that river water temperatures are not very sensitive to sewage inflows in warmer periods, mainly due to the fact that inflow temperatures are similar to those of natural flow. A clear increase of mean, maximum, and minimum water temperature metrics, although generally smaller in their magnitudes than those from sewage inflow, were observed also due to the lack of riparian trees and shrubs resulting from channel regulation (between U6 and U7), which was responsible for short-wave radiation heating of the water surface $[18,28]$. In turn, there was a noted cooling effect in terms of mean and maximum temperature metrics between sites S3 and S5-S6 due to the appearance of riparian shade in the nature reserve section.

Channel geometry was identified in some studies as an important driver of heat exchange processes with the atmosphere [29]; reaches with higher width:depth ratios are characterized in general by a greater daily temperature range, lower maximum, and higher minimum temperature. The current study confirms these findings; such an effect on longitudinal water temperature patterns was observed between sites S1 and S2, where a decrease of the maximum temperature and an increase of the minimum temperature were noted despite the lack of riparian vegetation shade on this reach. This can be associated with a deeper channel in site S2, in contrast to a more shallow channel in site S1, which prevented rapid daytime heating by solar radiation and fast nighttime cooling. Moreover, this was the main reason behind the substantial reduction of daily temperature fluctuations, which in site S2 were even smaller than in downstream sites (e.g., S7). A similar trend in terms of minimum and mean daily range was also found in the case of site $\mathrm{U} 2$ on the Utrata, located in the weir backwater, in comparison to the nearest sites: U1 or U3.

The effects of tributaries cannot be defined clearly. In the case of natural tributary inflow there was no impact on water temperature in the section below confluences because, as indicated by summer handheld measurements (not presented in this paper), the water temperature of tributaries varied by only $1-1.5^{\circ} \mathrm{C}$ from the studied rivers. This was visible in the case of sites S4 and S5, where no significant statistical differences were found for any temperature metrics downstream from the confluence. On the other hand, the thermal and flow regimes of several tributaries can be transformed themselves, for example due to significant wastewater inflow, and thus they could affect the thermal regime of the river below the mouth. One such example could be the Raszynka River - the confluence with the relatively high, thermally modified 
inflow of this river caused a cooling effect in site U5 on the Utrata.

\section{Air-Water Temperature Relationships}

Human impacts were visibly reflected in the explanatory power and parameters of linear regression models. In the case of the Utrata, slopes and intercepts of linear models were differentiated throughout all sites, which indicates that the potential response of the stream temperature to climate warming could be spatially varied in such transformed rivers. In consequence, the prediction of temperature must be careful and should be based on site-specific models. In turn, the small variability between parameters of regression models found in the less transformed Swider indicates that there is a possibility to perform simple statistical modelling for whole river sections. Furthermore, the current study is generally inconsistent with the suggestions of [30] that small catchments have lower correlations with air temperature. This was not found in the case of the upstream sites, e.g., S1 $\left(\mathrm{R}^{2}=0.84\right)$ and $\mathrm{U} 1\left(\mathrm{R}^{2}=0.89\right)$, similar to [31], who studied U.S. streams in southeastern Minnesota. It can be explained that such a tendency in model performance suggested by [30] is limited to very short stream reaches close to the source, especially in foothill and mountain streams supplied by cold, thermally stable springs (exsurgences), making temperature not very sensitive to atmospheric heat flux.

Air-water temperature relationships were widely used for stream temperature prediction in the face of climate warming [32], as well as for the identification of groundwater-fed sites, as linear models of such reaches have lower slopes and higher intercepts than their meteorological control counterparts [33]. In the present study, similar to groundwater effect, lower slopes and higher intercepts reflected sewage inflows $(\mathrm{a}=0.58$, $\mathrm{b}=8.02$ ) and the net result of tributary inflow and releases from reservoir $(\mathrm{a}=0.61, \mathrm{~b}=5.50)$; however, according to previous studies, typical groundwater-fed streams have generally lower regression slopes [31, 33]. In turn, the highest degree of meteorological control on stream temperature (e.g., the highest slope and the lowest intercept) was found directly in the site below the reservoir (U4), where the unshaded water surface was the most vulnerable to radiation heating $(a=0.86, b=3.35)$. It must be emphasized that despite the similar effect of sewage and groundwater inflows on the regression coefficients, the influence of these factors on the river thermal regime is definitely different. This suggests a great caution in such interpretations.

\section{Acknowledgements}

The author thanks the anonymous reviewer for his helpful suggestions. Research was financially supported by the University of Warsaw (grant No. 501/86-DSM110600).

\section{References}

1. CAISSIE D. The thermal regime of rivers: a review. Freshwat. Biol. 51, 1389, 2006.

2. GURNEY W.S.C., BACON P.J., TYLDESLEY G., YOUNGSON A.F. Process-based modelling of decadal trends in growth, survival, and smolting of wild salmon (Salmo salar) parr in a Scottish upland stream. Can. J. Fish Aquat. Sci. 65, 2606, 2008

3. SALINGER D.H., ANDERSON J.J. Effects of Water Temperature and Flow on Adult Salmon Migration Swim Speed and Delay. T. Am. Fish. Soc. 135, 188, 2006

4. BAIRD H.B., KRUEGER C.C., JOSEPHSON D.C. Differences in Incubation Period and Survival of Embryos among Brook Trout Strains. N. Am. J. Aquacult. 64, 233, 2002

5. VANNOTE R.L., MINSHALL G.W., CUMMINS K.W., SEDEL J.R., CUSHING C.E. River continuum concept. Can. J. Fish. Aquat. Sci. 37, 130, 1980.

6. WEBB B.W., HANNAH D.M., DAN MOORE R., BROWN L.E., NOBILIS F. Recent advances in stream and river temperature research. Hydrol. Process. 22, 902, 2008.

7. IMHOLT C., SOULSBY C., MALCOLM I.A., HRACHOWITZ M., GIBBINS C.N., LANGAN S., TETZLAFF D. Influence of scale on thermal characteristics in a large montane river basin. River Res. Applic. 29, 403, 2013.

8. HRACHOWITZ M., SOULSBY C., IMHOLT C. Thermal regimes in a large upland salmon river: a simple model to identify the influence of landscape controls and climate change on maximum temperatures. Hydrol. Process. 24, 3374, 2010

9. SIMMONS J.A., ANDERSON M., DRESS W., HANNA C., HORNBACH D.J., JANMAAT A., KUSERK F., MARCH J.G., MURRAY T., NIEDZWIECKI J., PANVINI D., POHLAD B., THOMAS C., VASSEUR L.A Comparison of the Temperature Regime of Short Stream Segments under Forested and Non-Forested Riparian Zones at Eleven Sites Across North America. River Res. Applic. 31, 964, 2015.

10. BROADMEADOW S.B., JONES J.G., LANGFORD T.E.L., SHAW P.J., NISBET T.R. The influence of riparian shade on lowland stream water temperatures in southern England and their viability for brown trout. River Res. Applic. 27, 226, 2011.

11. KANNO Y., VOKOUN J.C., LETCHER B.H. Paired stream-air temperature measurements reveal fine-scale thermal heterogenity within headwater brook trout stream networks. River Res. Applic. 30, 745, 2014.

12. TORGERSEN C.E., FAUX R.N., MCINTOSH B.A., POAGE N.J., NORTON D.J. Airborne thermal remote sensing for water temperature assessment in rivers and streams. Remote Sens. Environ. 76, 386, 2001.

13. FULLERTONE A.H., TORGERSEN C.E., LAWLER J.J., FAUX R.N., STEEL E.A., BEECHIE T.J., EBERSOLE J.L., LEIBOWITZ S.G. Rethinking the longitudinal stream temperature paradigm: region-wide comparison of thermal infrared imagery reveals unexpected complexity of river temperatures. Hydrol. Process. 29, 4719, 2015.

14. HANDCOCK R.N., TORGERSEN C.E., CHERKAUER K.A., GILLESPIE A.R., TOCKNER K., FAUX R.N., TAN J. Thermal infrared remote sensing of water temperature in riverine landscapes, Carbonneau P.E., Piégay H. (ed.), Fluvial remote sensing for science and management, Wiley, Chichester, 85, 2012. 
15. MARSZELEWSKI W., PIUS B. Long-term changes in temperature of river waters in the transitional zone of the temperate climate: a case study of Polish rivers. Hydrolog. Sci. J. 61, 1430, 2015.

16. SOMOROWSKA U., ŁASZEWSKI M. Human-influenced streamflow during extreme drought: identifying driving forces, modifiers, and impacts in an urbanized catchment in central Poland. Water Environ. J., 31, 345, 2017.

17. ŁASZEWSKI M. Relationships between environmental metrics and water temperature: a case study of Polish lowland rivers. Water Environ. J. 30, 143, 2016.

18. MALCOLM I.A., HANNAH D.M., DONAGHY M.J., SOULSBY C., YOUNGSON A.F. The influence of riparian woodland on the spatial and temporal variability of stream water temperatures in an upland salmon stream. Hydrol. Earth. Syst. Sci. 8, 449, 2004.

19. DRIPPS W., GRANGER S.R. The impact of artificially impounded, residential headwater lakes on downstream water temperature. Environ. Earth. Sci. 68, 2399, 2013.

20. OLDEN J.D., NAIMAN R.J. Incorporating thermal regimes into environmental flows assessments: modifying dam operations to restore freshwater ecosystem integrity. Freshwat. Biol. 55, 86, 2010.

21. XIN Z., KINOUCHI T. Analysis of stream temperature and heat budget in an urban river under strong anthropogenic influences. J. Hydrol. 489, 16, 2013.

22. PRATS J., VAL R., ARMENGOL J., DOLZ J. Temporal variability in the thermal regime of the lower Ebro River (Spain) and alteration due to anthropogenic factors. J. Hydrol. 387, 105, 2010.

23. LEBLANC R.T., BROWN R.D., FITZGIBBON J.E. Modeling the Effects of Land Use Change on the Water Temperature in Unregulated Urban Streams. J. Env. Manag. 49, 445, 1997.

24. JOHNSON M.F., WILBY R.L., TOONE J.A. Inferring air-water temperature relationships from river and catchment properties. Hydrol. Process. 28, 2912, 2014.
25. JOHNSON M.F., WILBY R.L. Seeing the landscape from the trees: Metrics to guide riparian shade management in river catchments. Water Resour. Res. 51, 3754, 2015.

26. LESSARD J.L., HAYES D.B. Effects of elevated water temperature on fish and macroinvertebrate communities below small dams. River Res. Applic. 19, 721, 2003.

27. KINOUCHI T., YAGI H., MIYAMOTO. Increase in stream temperature related to anthropogenic heat input from urban wastewater. J. Hydrol. 335, 78, 2007.

28. GARNER G., MALCOLM I.A., SADLER J.P., MILLAR C.P., HANNAH D.M. Inter-annual variability in the effects of riparian woodland on micro-climate, energy exchanges and water temperature of an upland Scottish stream. Hydrol. Process. 29, 1080, 2014.

29. HAWKINS C.P., HOGUE J.N., DECKER L.M., FEMINELLA J.W. Channel Morphology, Water Temperature, and Assemblage Structure of Stream Insects. J. N. Am. Benthol. Soc. 16, 728, 1997.

30. ERICKSON T., STEFAN H. Linear Air/Water Temperature Correlations for Streams during Open Water Periods. J. Hydrol. Eng. 5, 317, 2000.

31. KRIDER L.A., MAGNER J.A., PERRY J., VONDRACEK B., FERRINGTON Jr. L.C. Air-Water Temperature Relationships in the Trout Streams of Southeastern Minnesota's Carbonate-Sandstone Landscape. J. Am. Water. Resour. Assoc. 49, 896, 2013.

32. PEDERSEN N.L., SAND-JENSEN K. Temperature in lowland Danish streams: contemporary patterns, empirical models and future scenarios. Hydrol. Process. 21, 348, 2007.

33. O'DRISCOLL M.A., DEWALLE D.R. Stream - air temperature relations to classify stream - ground water interactions in a karst setting, central Pennsylvania, USA. J. Hydrol. 329, 140, 2006. 